\title{
CHANGES IN THE POPULATION STRUCTURE OF SLATINA CITY BETWEEN YEARS 1990-2000
}

\author{
Florentina MANOLEA CÎRJAN * \\ Alunișu Village Gymnasium School, Str. Principală, Alunișu, No.128, Spineni, Olt, România, e-mail: \\ manoleaflorentina905@gmail.com
}

Citation: Cîrjan, F.M. (2021). Changes in the Population Structure of Slatina City between Years 1990-2000. Revista Română de Geografie Politică, 23(1), 47-57. https://doi.org/10.30892/rrgp.231105-346

\begin{abstract}
The article is a contribution to the geographical study of the Slatina city in order to elucidate the impact of the economic and social transformations of 1990 - 2002 interval had on the evolution of its demographic phenomena, but also on understanding its socioeconomic profile. The research methodology consisted of a comparative analysis of the numerical values provided by the Olt Regional Directorate of Statistics. The measured parameters were: the numerical evolution and its causes, the structure by sexes and age groups, the structure of the active population, the ethnic structure, and according to the practiced religion. The results of the analysis show an evolution developed on the background of the existing one at national level, having as causes: a tendency of numerical decrease determined by the decrease in the birth rate, the opening of European borders, simultaneously with a decline of the national economy, rising unemployment and travel abroad for searching of a job. The article highlights two important conclusions: the economic transformations show the existing reality in the social and economic field, their impact on the socio-economic profile of the Slatina city; the same transformations have taken place at the national level, on the background of the same causes.
\end{abstract}

Key words: geographical, analysis, information, study, results, evolution, profile

\section{INTRODUCTION}

During my activity as a geography teacher, I also carried out: an economicgeographical study, in the work "The tourist potential of the relief and its capitalization in the Șureanu Mountains", a physical-geographical study - 
"Geographical study of the Motru river basin", and also a collection of " Recreational greography " exercises for middle school students.

The specialized literature gives priority to the analysis of the dynamic elements of the geographical phenomena, of great importance in research, including in the social and economic fields (Stupariu et al., 2016; Lung and Gligor, 2018; Filimon et al., 2019; Herman et al., 2020; Ilieș et al., 2020; Wendt, 2021).

In The Changing Distribution of World Population, Joseph Chamie (New York), a former director of the United Nations Population Division, on December 2019, shows that the momentous global changes in humanity's geographic distribution pose serious social, economic, political and environmental challenges and disquieting implications for the future.

In Principes de géographie humaine, Chapitre VI- Caractère géographique du progrès, page 211, Paul Vidal de la Blache said, referring to the geographical character of population progress, there is in these facts a distribution to which the purely geographical causes cannot be foreign.

My article aims at an analysis of the data that explains the logical relationships between statistical information and the population dynamics of Slatina. In his book, Élements de géographie humaine, Claval P. saw the city as "an organization of space that aims to promote the development of social relations and maximize them." Therefore, the investigated problem is important for knowing the social reality, the changes in the population structure of the city of Slatina between the targeted years, outlining and understanding its socioeconomic profile.

The research methodology consists of a comparative analysis of the data provided by the Olt Regional Directorate of Statistics, regarding: the population of the city at the censuses from 1992 and 2002, by age groups and sexes; the number of employees each year, from 1991-2000; the number of inhabitants according to the criterion of the mother tongue and an ethnic structure of the population; number of inhabitants according to the religion practiced; illustrative table of the evolution of birth and mortality; external migration of inhabitants.

The methodology is based on the comparative analysis of numerical values, which elucidates the changes in the population structure of Slatina between 1992 and 2002. The structure of the paper includes the key paragraphs of the study, respectively: the numerical evolution of the population, the structure by sex and age groups, the structure of the active population, the ethnic structure, and according to the criterion of the religion practiced.

Each subchapter offers, as results: the tendencies of numerical increase or decrease, the determining factors, the framing in the existing situation at the national level; a population structure by age groups and sexes illustrated by the comparative analysis of the age pyramids for 1992 and 2002; the ethnic structure of the population and the value of the share held by each ethnic group; a downward trajectory of the structure of the active population and an analysis of the determining factors; a picture of the population structure according to the criterion of the religion practiced.

\section{DATA ANALYSIS AND RESEARCH RESULTS}

Population problems are, in essence, problems of social and economic development, influenced by socio-economic factors. "Contemporary development reveals that between the evolution of the population in all its demographic 
aspects, and economic development, there is an indissoluble link, externalized by permanent mutual conditioning" (Velcea and Cucu, 1983, p. 159).

In other words, economic processes, mainly the increase of the production of material goods, therefore, of the standard of living, as well as the increase of the degree of culture of the population are phenomena characteristic of its development. At the same time, the integration of the local and regional labor force and the aspects of territorial mobility are phenomena with an impact on the development of the population, of its demographic evolution; the demographic behavior of families is directly proportional to the aspects of economic and sociocultural life. The demographic indicators, respectively, the birth rate and the mortality, register an evolution in correlation with these aspects.

Without proposing a very detailed approach to the relationship between population evolution and economic and social development, the study will analyze the data provided by the Regional Directorate of Statistics Olt, trying to outline existing determinants at the local and regional levels.

\section{ANALYSIS OF CHANGES IN THE POPULATION STRUCTURE OF SLATINA BETWEEN 1990-2002}

The structure of the population, defined as its mode of the organization from an economic, social, and cultural point of view, is analyzed as a structure by sex and age groups, by religions practiced, by ethnicities and mother tongue, by economic activities.

\section{NUMERICAL EVOLUTION OF THE POPULATION}

The numerical increase of the population is appreciated primarily according to the basic index deduced from the ratios between births and mortality (Cucu, 1981, p. 73). As can be seen from the analysis of the table below, in the interval studied, more precisely starting with the 1992 census, when the population of Slatina registered 85,168 inhabitants, it had a tendency of numerical decrease, registering after 10 years, at the census of the year 2002, 78,815 inhabitants, ie a decrease of 6,353 persons in the interval between the two censuses.

The analysis of the numerical value shows that until 2011, when the population registered 70,293 inhabitants, the numerical decrease continued, being with 8,522 inhabitants less than in 2002 and with 14,875 compared to 1992.

Table 1. Evolution of the city's population between 1992-2002-2011 Data provided by the Olt Regional Directorate of Statistics

\begin{tabular}{|c|c|c|c|}
\hline Town & \multicolumn{3}{|c|}{ Years } \\
\hline Slatina & 1.992 & 2.002 & 2.011 \\
\hline Total number of inhabitants & 85.168 & 78.815 & 70.293 \\
\hline
\end{tabular}

In 1992, the population of Slatina experienced a substantial increase compared to previous years, explained by the economic factor, respectively, the large number of industrial enterprises that appeared during the communist period, which attracted an active population from rural areas: Aluminum Factory (current ALRO), Aluminum Processing Company (former ALROM), Pipe Factory (now ARTROM), Electrocarbon, Bearings Factory and Food Equipment Factory (UTALIM). 
The same evolution is observed at the national level. If in 1990 the population of Romania was over 23 million inhabitants, at the 1992 census there was already a decrease to 22.8, and in 2000, of about 21 million. The numerical decline continued, due to the opening of the borders of European countries simultaneously with a period of decline in the national economy and rising unemployment, which allowed and provoked free movement abroad in search of a job; the decrease of the quality of life and the birth rate were also important factors of the numerical decrease of the population of Slatina, an existing phenomenon, moreover, at the national level.

At the 1992 census, the population of Slatina was 85,168 inhabitants, of which 42,202 were male and 42,966 were female. The figures indicate the existence of a young population, between 5 and 24 years old, with a numerical value of 33,897 inhabitants, which represents over $39 \%$ of the total. The value is more obvious if we make a comparison with the population included in the age category of 60-69 years, of only 4,172 inhabitants and which represents a percentage of only $4.89 \%$ of the total number. At the same census, the number of children between 0 and 4 years was 6,773, representing a percentage of $7.95 \%$.

An analysis compared to the data provided by the next census, from 2002, when the city of Slatina registered 78,815 inhabitants, a population of 3,280 children between 0 and 4 years and 3,090 inhabitants between 60 and 69 years, shows a numerical decrease of the population with 6,353 inhabitants; a decrease in the number of children between 0 and 4 years, by $50 \%$; a decrease in the number of the population included in the age category of 60-69 years which represents $3.92 \%$ of the total.

The numerical decrease of the population and the number of children between 0 and 4 years, by 50\% were due to the decrease of the birth rate between 1990-2002, as follows: in 1990, the birth rate registered a value of 1,261 , higher than in the following years; 1064 in 1991; 862 in 1994; 910 in 1998; 811 in 2000, 718 in 2001; 725 in 2002.

In the same period, mortality remains between 378 and 500 deaths per year, which reflects a positive natural increase, which could translate into a numerical increase in population. Unfortunately, this situation of the natural movement of the population (birth rate, mortality, and natural increase) overlaps, over time, with the closure or reduction of the operating capacity of some valuable industrial enterprises, which included a large number of the active population of the city of Slatina, following the decision of the postDecember governments; the reduction in the number of jobs has led to a decrease in living standards, an external migratory movement in search of a job, a temporary or permanent departure from the city of a number of people, a visible reduction in the birth rate and, consequently, a decrease in the total population. The same situation was registered at the national level, after 1990, when the population started to decrease gradually.

On the list of the 1,256 national enterprises disbanded or which have reduced their working capacity, there are also enterprises from the city of Slatina that included most of its active population: Industrial Factory for non-ferrous and rare materials - its own activity; Aluminum Processing Company - Alprom; Coal Products Company - Electrocarbon; Food Equipment Company; "Textila" enterprise; Vine and Wine Enterprise; Meat Industrialization Enterprise; Milling, Bakery and Flour Products Enterprise. 


\section{External migratory movement}

The reduction in the number of jobs, as a result of the abolition of industrial enterprises, has led to a decrease in living standards, an increase in unemployment, and, implicitly, an external migratory movement in search of a job. Slatina experienced a temporary and permanent migration of some families, in order to find a job in another European country. The data provided by the Olt Regional Directorate of Statistics illustrate the number of families in the category of permanent emigrants in the studied interval, more precisely between $1994-2002$.

Table 2. External migration

\begin{tabular}{|c|c|c|c|c|c|c|c|c|c|}
\hline Town & \multicolumn{10}{|c|}{ Years } \\
\hline Slatina & 1994 & 1995 & 1996 & 1997 & 1998 & 1999 & 2000 & 2001 & 2002 \\
\hline & 17 & 33 & 19 & 65 & 58 & 41 & 68 & 33 & 8 \\
\hline
\end{tabular}

If we add to these values a significant number of people who have gone abroad illegally, without an employment contract, for undeclared work, the number of unemployed families who have moved to rural areas, and a significant reduction in the birth rate, then we have a clear image of the factors that caused the numerical decrease of the population of Slatina in this interval.

\section{POPULATION STRUCTURE BY SEX AND AGE GROUPS}

The structure of the population by age groups illustrates the numerical value of the population groups and, within them, the male and female populations. The structure of the population by sex and age groups is conditioned by the natural dynamics of the population (birth rate, mortality, natural increase) and by the migratory one. It helps to know the potential of labor resources and future economic and social development.

Table 4. Population structure by age groups and sexes

\begin{tabular}{|c|c|c|c|c|c|c|c|c|c|}
\hline \multicolumn{5}{|c|}{ Total population, by groups and sexes } & \multicolumn{5}{|c|}{ Age Groups (Years) } \\
\hline $\mathrm{T}$ & M & $\mathrm{F}$ & $\begin{array}{c}\text { Between } \\
0-4: \\
\mathrm{T} / \mathrm{M} / \mathrm{F}\end{array}$ & $\begin{array}{c}\text { Between } \\
5-14: \\
\mathrm{T} / \mathrm{M} / \mathrm{F}\end{array}$ & $\begin{array}{r}\text { Between } \\
15-24: \\
\mathrm{T} / \mathrm{M} / \mathrm{F}\end{array}$ & $\begin{array}{c}\text { Between } \\
25-39: \\
\text { T/M/F }\end{array}$ & $\begin{array}{c}\text { Between } \\
40-59 \\
\mathrm{~T} / \mathrm{M} / \mathrm{F}\end{array}$ & $\begin{array}{c}\text { Between } \\
60-69: \\
\mathrm{T} / \mathrm{M} / \mathrm{F}\end{array}$ & $\begin{array}{c}\text { Over } \\
70: \\
\text { T/M/F }\end{array}$ \\
\hline 85.168 & 42.202 & 42.966 & $\begin{array}{l}6.774 \\
3.486 \\
3.288\end{array}$ & $\begin{array}{r}18.817 \\
9.592 \\
9.225\end{array}$ & $\begin{array}{c}15.070 \\
6.904 \\
8.166\end{array}$ & $\begin{array}{l}24.678 \\
11.916 \\
12.762\end{array}$ & $\begin{array}{l}15.655 \\
8.483 \\
7.172\end{array}$ & $\begin{array}{l}2.616 \\
1.234 \\
1.382\end{array}$ & $\begin{array}{c}1.558 \\
587 \\
971\end{array}$ \\
\hline
\end{tabular}

Table 5. Population structure by age groups and sexes

\begin{tabular}{|c|c|c|c|c|c|}
\hline \multicolumn{2}{|c|}{ Total population, by groups and sexes } & \multicolumn{4}{|c|}{ Age Groups (Years) } \\
\hline $\mathrm{T}$ & $\mathrm{M}$ & $\mathrm{F}$ & Between $0-19$ & Between $20-59$ & Over 60 \\
\hline \multirow{2}{*}{85.168} & \multirow{2}{*}{42.202} & \multirow{2}{*}{42.966} & $\mathrm{~T}: 33.931$ & $\mathrm{~T}: 47.423$ & $\mathrm{~T}: 4.174$ \\
& & & $\mathrm{M}: 16.977$ & $\mathrm{M}: 23.404$ & $\mathrm{M}: 1.821$ \\
& & & $\mathrm{~F}: 16.954$ & $\mathrm{~F}: 24.019$ & $\mathrm{~F}: 2.353$ \\
\hline
\end{tabular}

Statistics usually use 5-year intervals, but also intervals of 0-14 years, 1559 years, and 60 years and over, to analyze and know the potential of labor resources and the situation of the employed population. For the analysis of the young population, the intervals of 0-19 years, of the adult of 20-59 years, of the elderly of 60 years and over are usually used. The tables below, drawn up according to the data provided by the Olt Regional Directorate of Statistics, 
illustrates the structure of the population of Slatina municipality registered through the censuses from 1992 and 2002, by age groups and sexes.

The situation illustrated by the 1992 census.

Table 6. Situation illustrated by the 2002 census

\begin{tabular}{|c|c|c|c|c|c|c|c|c|c|}
\hline \multicolumn{4}{|c|}{ Total population } & \multicolumn{8}{c|}{ Age Groups (Years) } \\
\hline \multirow{2}{*}{$\mathrm{T}$} & $\mathrm{M}$ & $\mathrm{F}$ & $\begin{array}{c}0-4 \\
\mathrm{~T} / \mathrm{M} / \mathrm{F}\end{array}$ & $\begin{array}{c}5-14: \\
\mathrm{T} / \mathrm{M} / \mathrm{F}\end{array}$ & $\begin{array}{c}15-24 \\
\text { ani: } \\
\mathrm{T} / \mathrm{M} / \mathrm{F}\end{array}$ & $\begin{array}{c}25-39 \\
\text { ani: } \\
\mathrm{T} / \mathrm{M} / \mathrm{F}\end{array}$ & $\begin{array}{c}40-59 \\
\text { ani: } \\
\mathrm{T} / \mathrm{M} / \mathrm{F}\end{array}$ & $\begin{array}{c}60-69 \\
\mathrm{~T} / \mathrm{M} / \mathrm{F}\end{array}$ & $\begin{array}{c}\text { Over } \\
\mathrm{T} / \mathrm{M} / \mathrm{F}\end{array}$ \\
\hline 78. & \multirow{3}{*}{38.442} & \multirow{2}{*}{40.373} & 3280 & 11.197 & 15273 & 20.837 & 23.135 & 3.090 & 2.046 \\
& & & 1683 & 5.694 & 7.645 & 9.494 & 11.698 & 1.419 & 809 \\
1.67 & 1597 & 5.503 & 7.628 & 11.343 & 11.437 & 1.671 & 1.237 \\
\hline
\end{tabular}

Table 7. Situation illustrated by the 2002 census

\begin{tabular}{|c|c|c|c|c|c|}
\hline \multicolumn{2}{|c|}{ Total population by sex } & \multicolumn{4}{|c|}{ Age Groups } \\
\hline $\mathrm{T}$ & $\mathrm{M}$ & $\mathrm{F}$ & between 0 - 19 & between 20 -59 & Over 60 \\
\hline \multirow{3}{*}{78.815} & \multirow{2}{*}{38.442} & \multirow{2}{*}{40.373} & $\mathrm{~T}: 23.212$ & $\mathrm{~T}: 61.887$ & T: 5.154 \\
& & & $\mathrm{M}: 11.792$ & M:24.422 & M: 2.246 \\
& & & F: 11.420 & F: 37.465 & F: 2.908 \\
\hline
\end{tabular}

\section{Analysis of the situation at the 1992 census}

The processing and analysis of the data from tables 4, 5 highlight the following aspects:

- the number of inhabitants between 0 and 24 years was 40,661, representing $47.74 \%$ of the total population.

- between 25 and 59 years old, the city of Slatina registered 40,333 people, which represents a percentage of $47.35 \%$. These two values indicate the existence of more than $90 \%$ of a young and adult population.

- the elderly population represents only about 4,174 inhabitants, respectively, $4.90 \%$ of the total population.

Table 4 , based on age intervals that allow the analysis of the young, adult, and elderly population, highlights:

- a young population (between 0 and 19 years old) of 33,931 inhabitants, representing $39.84 \%$ of the total;

- the dominance of the adult population (between 20 and 59 years old), numbering 47,423 , ie $55.68 \%$ of the total;

- an elderly population (over 60 years old) of 4,174, holding $4.90 \%$.

\section{Situation recorded during the 2002 census}

Taking into account the same age groups, it can be observed:

- the existence of 29,750 inhabitants between 0 and 24 years old, ie $37.74 \%$;

- 43,972 inhabitants between 25 and 59 years old, ie 55.79\%; of $6.53 \%$.

- 5,154 persons belonging to the interval of over 60 years, in the proportion

Table 7, made on the basis of age ranges that allow the analysis of the young, adult, and elderly population, shows:

- a young population (between 0 and 19 years old) of 23,212 people, representing $29.45 \%$ of the total number;

- a dominance of the adult population (between 20 and 59 years old) of 61,887 , representing $78.52 \%$ of the total; 
- an elderly population (over 60 years old) of only 5,154 inhabitants, respectively $6.53 \%$.

A comparative analysis between the existing data from the two censuses, from 1992 and 2002, processed in the above tables, can draw conclusions on the changes suffered by the structure of the population by age groups, which will better illustrate the notions of young, adult and elderly population, but also aspects regarding its evolution (rejuvenation, maturation, aging), as follows:

- decrease in the number and share of the population between 0 and 4 years, from 6,774 people and a percentage of $7.95 \%$ in 1992 to 3280 people and a percentage of $4.16 \%$ in 2002; the change of these values occurs in the conditions of the decrease of the birth rate, from 1261 to 725 live births;

- a decrease in the number of young people (0 -19 years), from $39.84 \%$ in 1992 to $29.45 \%$ in 2002, amid a significant decrease in the total number of the population with 6,353 inhabitants and the birth rate, of in 1261 to 725 live births;

- an increase and a numerical dominance of the adult population, at both censuses, of $55.68 \%$ of the total in 1992 , to $78.52 \%$ in 2002 ; the high percentage existing in 2002 occurs against the background of a decrease of the total population by 6,353, but supported by the existence of a higher number of young population (0 -19 years) at the beginning of the interval (1992), of 33,931 compared to 23,212 in 2002 ;

- the increase of the percentage of the elderly population (over 60 years old) from $4.90 \%$ of the total to $6.53 \%$, simultaneously with the decrease of the birth rate;

- comparing with the existing situation at the national level, it can be seen that the city of Slatina experienced the same general situation: a decreasing trend of the share of the young population at the same time with an upward trend of the share of the elderly population and an increase of adult population. translated into a gradual phenomenon of demographic aging.

\section{Calculation of the demographic type of the city of Slatina}

The ratio between the population over 60 years old and the one up to 20 years old, gives us the image of the demographic type, as follows: a ratio with values below 0.50, shows a young demographic type; a ratio between 0.51 and 0.70 , illustrates a moderate demographic type; a ratio between 0.71 and 0.90 highlights a matured demographic type; a ratio exceeding 0.90 shows an aging demographic (Iordache, 2009, p. 98).

Thus, at the level of 1992, the ratio between the population over 60 years old $(4,174$ inhabitants) and the one under 20 years old $(33,931)$ was 0.12 , specific to a young demographic type.

In 2002, the ratio between the number of the population over 60 years old $(5,154$ inhabitants) and the one under 20 years old $(23,212)$ was 0.22 , also specific to a young demographic type.

\section{Population structure by sex}

This structural category refers to the distribution of the population by the two sexes, male and female. It is assessed by the share of the total population and by the ratio between the two values of the male and female population. It is closely related to natural dynamics (the number of born male or female) and population migration.

At the national level, the population has experienced a slight increase in numbers among women since 1930, explained by a higher value of male 
mortality and a higher share at birth. There are, however, differences by age groups.

Regarding the city of Slatina, the phenomenon can be easily illustrated by the Age Pyramids corresponding to the years of analysis 1992 and 2002, (figures 1 and 2).

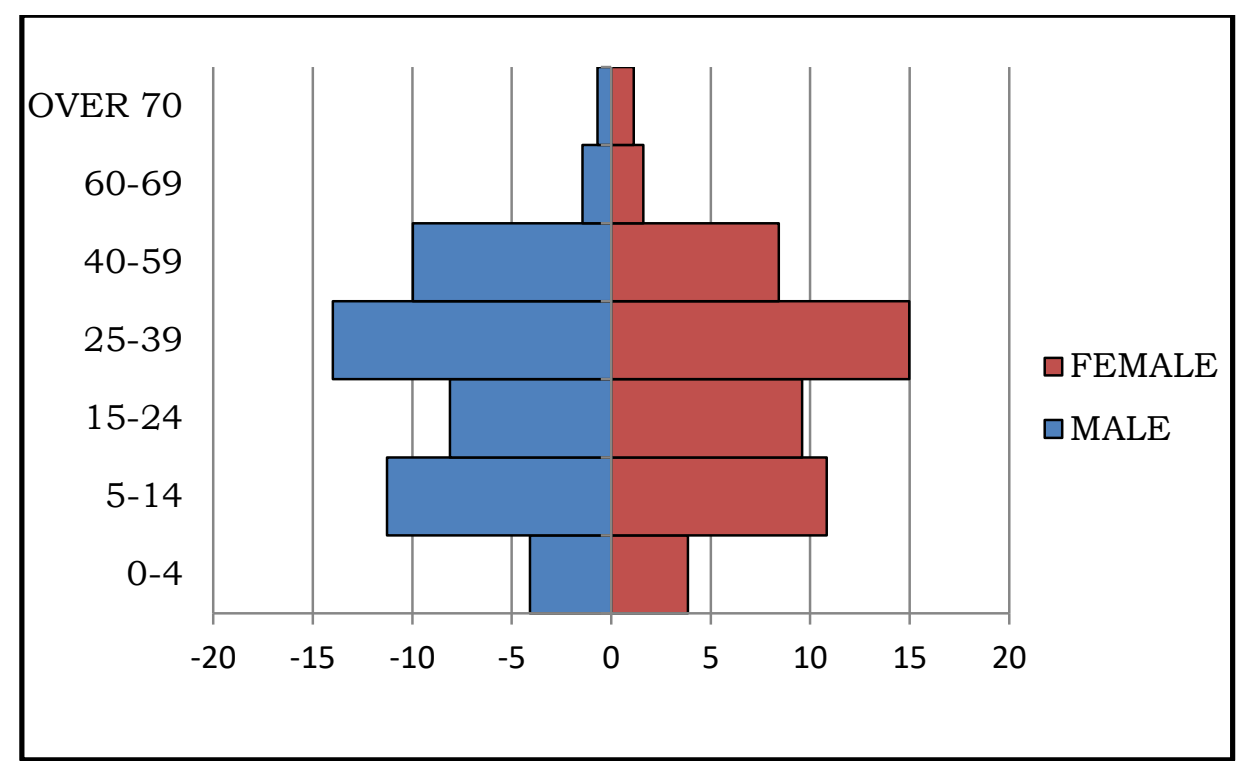

Figure 1. Age Pyramid, 1992

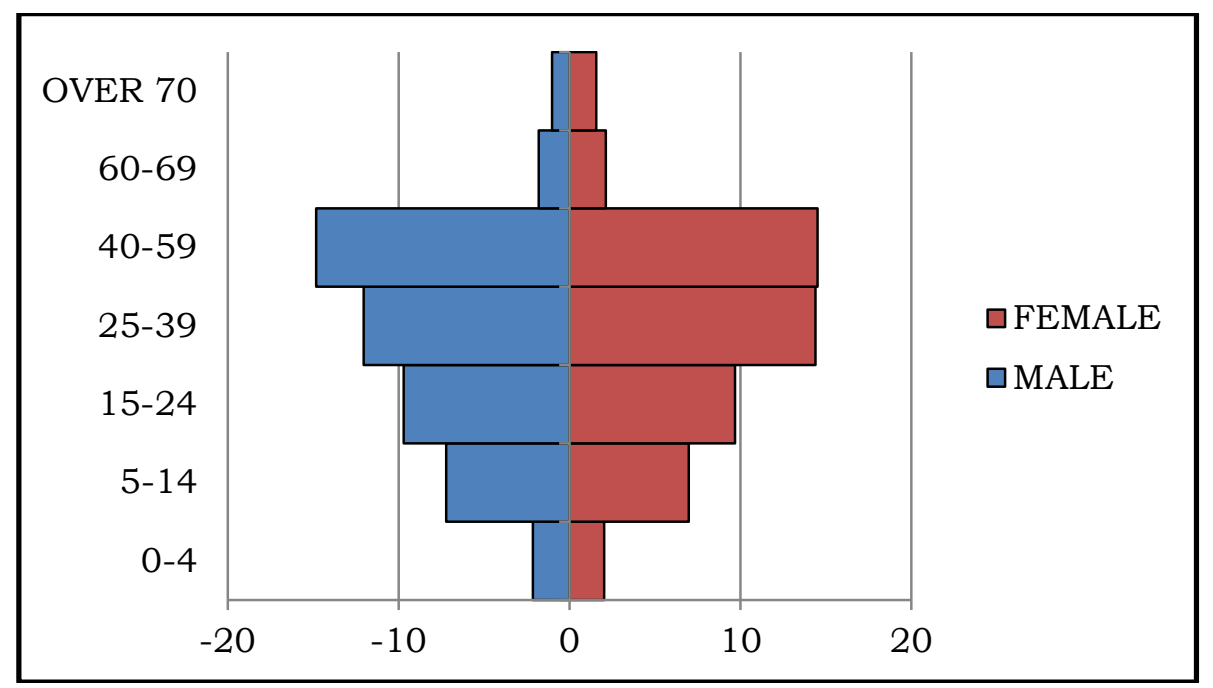

Figure 2. Age Pyramid, 2002

In the analysis of the population by sex, there are differentiations at the level of age groups, as follows:

- regarding 1992, the Age Pyramid (figure 1) and tables 4, 5, in the age category $15-24$, ie among the young population, there is a domination of the 
female population, with 1262 people compared to the male population. The same dominance is observed in the age category of 25-39 years, with 846 people. These differences say that the city of Slatina had the capacity to provide female labor, especially for the light and food industry. In the other age categories, the ratio between the female and the male population seems balanced, even a decrease in the number of the female population.

- regarding the year 2002, the data included in the Age Pyramid (figure 2) and tables 6,7 indicate the dominance of the female population in the age category 25 -39 years, where there was a difference of 1849 people. Also, among people over 60 , it is observed that the number of the female population exceeds that of the male population, but this category, mostly belonging to the inactive population, does not introduce important economic aspects for the economy of Slatina.

\section{THE STRUCTURE OF THE ACTIVE POPULATION}

According to this socio-economic indicator, which expresses the distribution of the population by economic activities, two branches are known: active population and inactive population. The active population knows the employed active population and the active unemployed population; the latter may be job-seeking population. The inactive population is the one that does not carry out an economic-social activity, examples: pupils, students, pensioners, persons in state maintenance.

Regarding the years 1991-2000, the active population of the city of Slatina followed a downward path from 52,502 to 31,701 people, even to 30,945 in 2002 (table 8).

Table 8. Average number of employees

\begin{tabular}{|c|l|c|c|c|c|c|c|c|c|c|c|c|}
\hline Town & \multicolumn{10}{|c|}{ YEARS } \\
\hline Slatina & 1991 & 1992 & 1993 & 1994 & 1995 & 1996 & 1997 & 1998 & 1999 & 2000 & 2001 & 2002 \\
\hline- & 52502 & 46563 & 45541 & 43637 & 44655 & 42025 & 40549 & 36192 & 32001 & 31701 & 34556 & 30945 \\
\hline
\end{tabular}

While in 1992, the employed population of Slatina represented $52.87 \%$ of the total, in 2002 , it recorded only $39.26 \%$. The causes that led to this situation were: a period of decline and destruction of the city's economy but also nationally, layoffs caused by the abolition of major industrial enterprises in the city, privatizations, early retirement, all visible after the revolution of December 1989. The same downward trajectory of the active population was registered at the national level.

\section{THE ETHNIC STRUCTURE OF THE POPULATION}

In the analysis of this category, the number of the population of Romanians, Roma, and a structure of the population according to the spoken mother tongue was taken into account.

Thus, in 1992, out of the total population of 85,168 inhabitants, the Romanian population was 84,541 , holding the largest share of $99.27 \%$, followed by the Roma population of 452 inhabitants - $0.54 \%$ and a number of 111 inhabitants of Hungarian ethnicity representing $0.13 \%$. With a share of only $0.06 \%$, there are populations of other ethnicities: Germans, Ukrainians, Serbs, Russians, Jews.

In 2002, out of a total of 78,815 people, the ethnic structure was illustrated by the same predominance of the Romanian population, of 77,918 
inhabitants, respectively $98.86 \%$, followed by the Roma population in a number of 761 and a share of $0.96 \%, 56$ of Hungarians holding $0.07 \%$. With a share of only $0.11 \%$, there are populations of other ethnicities, especially Germans, Turks, and Italians, settled in the city for business.

\section{THE STRUCTURE OF THE POPULATION ACCORDING TO THE CRITERION OF THE PRACTICED RELIGION}

In 1992, out of the total population of 85,168 inhabitants, the Orthodox religious cult held $99.26 \%$, followed by the Roman Catholic and Greek Catholic worship of only $0.26 \%$. With a small share, there are populations of various religions: Adventist, Baptist, Evangelical, Reformed, Muslim, etc. There were also 43 atheists.

The year 2002 stands out with a share of $98.86 \%$ of the population of Orthodox religion, followed by the Roman Catholic and Greek Catholic worship of $0.33 \%$. Compared to 1992 , there is a slight increase in the population of the Muslim, Adventist, and Baptist religions.

\section{CONCLUSIONS}

The results obtained through a comparative analysis can serve to understand the existing reality in the social and economic field in the city of Slatina, the impact that the economic transformations had the socio-economic profile of the city.

The study will be followed by two other articles on the same topic, on the city of Slatina in the following intervals, respectively, 2000 -2010, $2010-2020$, which can provide a broad picture of changes in the population structure from December 1990 to the present.

The results highlighted by the article can be used by practitioners to study and understand the natural development potential and socio-economic profile of Slatina, as a model in the analysis of other regions and to understand the existing context at the national level.

I would like to thank the Olt Regional Directorate of Statistics, which provided me with the existing information in its archive, from the reference intervals.

The article was made with my own sources of funding.

\section{REFERENCES}

Chamie, J. (2019). The Changing Distribution of World Population - Global Issues. www.globalissues.org/news

Claval, P. (1974). Eléments de géographie humaine, Paris, 1974 - Notes et comptes rendus - contraintes économiques et sociales.

Cucu, V. (1981). Geografia populației şi aşezărilor umane. Editura Didactică şi Pedagogică.

Direcția Regională de Statistică Olt, compartimentul de Statistică Regională, Sinteze, Inspire, Diseminare şi Relații cu Publicul.

Filimon, C., Filimon, L., Herman, G. V., \& Garai, L. D. (2019). The Human Capital in the Underprivileged Mountain Areas of Bihor County. Analele Universității din Oradea, Seria Geografie, 29(2), 181-193.

Herman, G. V., Ilieș, D. C., Dehoorne, O., Ilieș, A., Sambou, A., \& Caciora, T. (2020). Emitter and tourist destination in Romania. Baltic Journal of Health and Physical 
Activity, 12(1), 120-138.

Ilies, M., Herman, G., Hodor, N., Baias, S., \& Ilies, A. (2020). The Dynamics, Structure and Spatial Distribution of the Religious Choices of the Romanian Ethnic Community in the Post-Socialist Period (1992-2011). Journal for the Study of Religions and Ideologies, 19(57), 163-185.

Iordache, C. (2009). Geografia populației si așezărilor umane din România, Editura Universitaria, Craiova, page 98.

Lung, M. S., \& Gligor, V. (2018). Demographic Changes in the Urban Space of Apuseni Mountains. Analele Universitatii din Oradea, Seria Geografie, 28(2), 164-173.

Stupariu, M. I., Herman, G. V., \& Grama, V. (2018). The structure of migration flows from Romania to Italy (2008-2016). Revista Româna Geografie Politica, 20(1), 5-16.

Velcea, V., \& Cucu, V. (1983) Sinteze geografice, material pentru perfecționarea profesorilor, Editura Didactica si Pedagogică, București, page 159.

Vidal de La Blache, P. (1922). Principes de géographie humaine, Internet Archive, Chapitre VI- aractere géographique du progrès, page 211.

Wendt A. J. (2021). Populations as Determinant of Latvia's Security. Revista Română de Geografie Politică, 23(1), 22-28.

https://ro.wikipedia.org/wiki/Slatina,_Rom\%C3\%A2nia, accesat la 1.02.2021.

Submitted:

February 05, 2021
Revised:

May 20, 2021
Accepted and published online: June 29, 2021 